\title{
A First World War example of Forensic Archaeology \\ Victoria Martin
}

\section{Introduction}

Modern Forensic Archaeology is the practice of locating areas where something is or has been buried, and carrying out excavation, while working within a legal framework and potentially gathering evidence to be used in criminal investigation. This could apply to clandestine burials, mass graves, drugs, weapons, or other forms of contraband that have been buried (Hunter and Cox, 2005). It has been described as "the application of archaeological (and taphonomic) theories and methodology - mostly related to buried or otherwise concealed human remains in criminal or medico-legal casework" (Groen, Márquez-Grant and Janaway, 2015, p.519). In some cases, Forensic Archaeology is not used for the gathering of evidence, but instead for the locating of human remains following mass disasters or mass fatality events. Haglund (2002, p261) states that in cases such as these "personal identification is the traditional goal of the recovery of human remains".

It is documented that the earliest example of forensic excavation can be traced to 1943, when Nazi Germany carried out an excavation in a Russian forest to locate the bodies of executed Polish prisoners (Haglund, Connor and Scott, 2001). At the end of Second World War, further excavations took place which led to the examination and analysis of bodies belonging to soldiers and holocaust victims (Mant, 1987). More recently, Forensic Archaeology became more mainstream both domestically and internationally during the 1980s, with forensic excavations having taken place in countries including Argentina (Steele, 2008), Former Yugoslavia (Sterenberg, 2009), Iraq (Steele, 2008), Serbia (Djuric et al., 2007) and Spain (Fernandez-Alvarez et al., 2016; Gassiot Ballbé and Steadman, 2008). These excavations took place either for humanitarian, legal or historical purposes, or a combination of these (Juhl and Einar Olsen, 2006). Some excavations were state sponsored, others requested and managed by international organisations such as the United Nations (UN).

Recently there has been a surge of excavations related to First World War burials in France and Belgium. The most well-known and documented of these was the Forensic Archaeology excavation which took place at Fromelles (Loe et al., 2014), demonstrating the potential role of forensic practice within more traditional archaeological fieldwork, as well as the current interest around body recovery and identification on the Western Front.

These and other examples have been well documented, however there is an earlier instance of state sponsored Forensic Archaeology in Europe, seen in France and Belgium and conducted by the British Army between 1919 and 1921, which has not been widely discussed or explored. It concerns the recovery of the British and Commonwealth dead on an unprecedented scale for the purposes of identification and reburial. Unlike modern Forensic Archaeology, the aim was not to gain evidence of criminal activity or confirm cause of death. Instead, it was conducted for humanitarian reasons rather than legal reasons, making it distinct to the modern Forensic Archaeology we see today. However, the processes followed are directly comparable to some of the modern-day techniques used in the search for clandestine and mass graves. 


\section{Concentration of Battlefield Graves}

Between 1914 and 1918, the First World War was fought across the globe, causing the deaths of millions of soldiers and civilians. On the battlefields of France and Belgium, years of trench warfare led to the deaths of hundreds of thousands of British and Commonwealth soldiers. The location of a soldier at the time of their death had a great impact on how and where they were buried (Taylor, 2015). There were three main possibilities; death in a position held by friendly troops, death behind enemy lines or death in no man's land (on the battlefield between the fighting lines) (Robertshaw and Kenyon, 2008). For deaths behind the front line in friendly territory, these soldiers would be given some kind of burial in a grave which was normally marked and recorded (Longworth, 1985). However, for battlefield deaths, this was more difficult and sometimes impossible. Many bodies were buried in shallow graves or artillery holes, often with other bodies (Hanson, 2005). Some soldiers were buried by falling earth and debris, while others were not fortunate enough to be buried at all (Desfosses, Jacques and Prilaux, 2009). Movement of the front meant that even those who had been buried might have burial markers lost, or be otherwise disturbed by later fighting and shell damage (Brown and Osgood, 2009). By the end of the conflict, this had been the fate for many soldiers, and hundreds of thousands of bodies had been lost along the Western Front.

Alongside the lost remains were thousands of single graves or small cemeteries that had been created across the landscape during the war. In 1918, it was estimated that about 160,000 single and small clusters of British and Commonwealth graves existed in France and Belgium (Imperial War Graves Commission, 1918). It had been decided during the war that at the end of the conflict, large war cemeteries would be designed and built, and the single graves and small cemeteries of less than 40 graves would be moved into the new cemeteries (Crane, 2013). This process was called concentration. In the two and a half years following the armistice, the battlefields were repeatedly searched for lost bodies, single marked graves and small cemeteries, which were exhumed, examined and reburied in new or expanded cemeteries. In this period over 204,000 British and Commonwealth individuals were located and concentrated in France and Belgium (Imperial War Graves Commission, 1931a).

\section{Directorate of Graves Registration and Enquires}

It had been the responsibility of the Directorate of Graves Registration and Enquires (DGRE) to register the graves of British and Commonwealth soldiers during the war, keeping detailed lists of the grave locations and the bodies contained within (Longworth, 1985). After the armistice, the DGRE was given the task of managing the concentration work. Soldiers were asked to volunteer to undertake the DGRE concentration task (Hanson, 2005), either in exhumation teams, responsible for the search and exhumation of graves, or cemetery teams, responsible for the digging of new graves and reburial of bodies. Most of the early work of exhumation and reburial was undertaken by volunteers from the Labour Corp; these volunteers had no medical, forensic, archaeological or anthropological training or experience.

In July 1919 Captain Crawford of the $68^{\text {th }}$ Labour Corp wrote "For the Guidance of Exhumation Companies in the Future", which contained detailed instructions for exhumation and cemetery parties (Crawford, 1919, cited in War Office, 1921). The $68^{\text {th }}$ Labour Corp had been one of the first units to volunteer for concentration duties in January 1919, and this guidance document 
was developed by Crawford, based on his own experiences while working on concentrations between January and July of that year. This document was issued to all DGRE staff and contained instructions for exhumation parties to follow when searching for graves, alongside further instruction for the exhumation, identification and reburial of soldiers' bodies (War Office, 1921). These were probably the earliest written guidelines for Forensic Archaeological recovery.

The process exhumation teams followed was simple; each day a group of DGRE staff would be given an area to search and a record of the graves that were known to be buried in that area. Their aim was to locate any graves, exhume the bodies buried there, and try to identify them. Following the examination, the body would be transported to the nearest cemetery that was open for concentration and would be reburied (Martin, 2020). Vanezis (1999, p.239) writes that when planning a forensic excavation of a mass grave the following work must be undertaken; "planning, bringing together the team, executing the task efficiently, documentation and presentation of evidence where necessary". This is very similar to the process followed during concentration. The following are part of the stages identified by Crawford (1919).

\section{Searching}

Once at the location, the first stage was to carry out a detailed ground search. The method for initial searching of the area is very similar to the method used for area searching now. Crawford's instructions state:

"The square must first be thoroughly searched. A small portion should be worked at a time, and completely cleared before an advance is made. Advantage should be taken of natural features where possible, as it is found much easier to search the area, say, between a road and a trench or a line of pill boxes than to work upon imaginary lines between flags... Wherever a body is found a stake is to be planted" (Crawford, 1919, cited in War Office, 1921)

Modern day searching often follows the same basic principle. Currently large areas are often still searched manually, with the area being divided and searched using physical features as natural boundaries, as described by Crawford. During the ground search, if there are any surface indications of buried features, these areas of interest are marked for investigation once the search is complete (Holland and Connell, 2016, pp.168-169). Areas of interest are then investigated further, now using modern techniques such as Ground Penetrating Radar (GPR) or trial trenching prior to excavation (Cox et al., 2008). Crawford gave specific descriptions of potential grave features in the following section, "grave identification".

\section{Grave identification}

Crawford had identified common indicators for the presence of graves or bodies.

"INDICATIONS OF GRAVES: Experience only teaches a man where bodies will probably be found, in graves which are not visible; but the following signs are characteristic;

1. Rifles, or posts bearing helmets or equipment, placed at the head of graves

2. Small stakes marked "E" (burnt into the wood) showing spots where British soldiers have been buried by Germans. In some cases these stakes bear a number instead of the letter $E$, 
but in the majority of such cases troops other than British have been buried there. Such bodies, however, should be exhumed, in as much as every body, whether Allied or enemy forces must be concentrated

3. Remains of equipment upon the surface or protruding from the ground

4. Rat-holes. These sometimes will show small bones or pieces of equipment brought to the surface by the rats

5. Discoloration of grass, earth or water. Grass is often a vivid bluish-green colour where bodies are buried, while earth and water turn a greenish black or grey" (Crawford, 1919, cited in War Office, 1921)

Here Crawford is describing the features that could be seen above ground when human remains were present underneath. The makeshift marking of graves was common in areas where graves could not be registered, and it was normal to find improvised markers such as those described here (Hanson, 2005). Crawford also instructed exhumation staff to search for small bones or pieces of equipment that had been brought to the surface. Scavenger activity is common for remains which have been placed in shallow burials, causing the presence of small bones as described (Hunter and Cox, 2005). In cases involving mass graves, on surface presence of bone fragments has been used as an indicator of grave location (Hunter et al., 2001).

Following death, as well as being subject to animal activity, decomposition starts. The graves being concentrated were in varying levels of decay depending on how, when and where they had been buried (Fathi, 2018). The rate and level of decomposition is dependent on temperature, water levels, oxygen levels, insects and burial depth (Chamberlain and Parker Pearson, 2001). As decomposition takes place, there is a release of nutrients and energy into the surrounding area, which can be seen as changes to soil, water and vegetation (Forbes, Perrault and Comstock, 2017, p.32). For example, greater vegetation growth of a more vivid colour is seen in areas of burial due to the nutrients released (Junkins and Carter, 2017, p.150). Similarly, decomposition enriches the soil, which can cause the soil to appear darker (Holland and Connell, 2016, p.169) as described by Crawford. The instructions show a clear awareness of the localised changes to the environment caused by decomposition.

Following the location of potential grave sites, the exhumation team would start to dig in the vicinity to locate any human remains present (see Figure 1).

\section{Exhumation}

"In the actual work of exhumation the men should be warned not to dig too closely to the bodies, but well outside them. Such a precaution renders the work easier, prevents disturbance of the bodies, and most important of all, reveals whether more than one man is buried at any particular spot.” (Crawford, 1919, cited in War Office, 1921).

Similarly, modern mass grave excavation is concerned with the same problem of multiple remains being present in one location (Garrido Varas and Intriago Leiva, 2012). Recent mass graves have included trenches, where bodies are in minimal contact, through to larger pits, which represent a much more complex environment with intermingled remains (Haglund, 2002). Excavation is therefore very important in ensuring that a body is excavated completely, as poor excavation can result in disarticulation of remains, and body parts being missed (Tuller 
and Durić', 2006, p.193). This was a problem that occurred in the concentration work; later reexamination of a sample of concentrated bodies at Hooge Crater Cemetery found that $13 \%$ of human remains were missing either the feet, head or both (Martin, 2020).

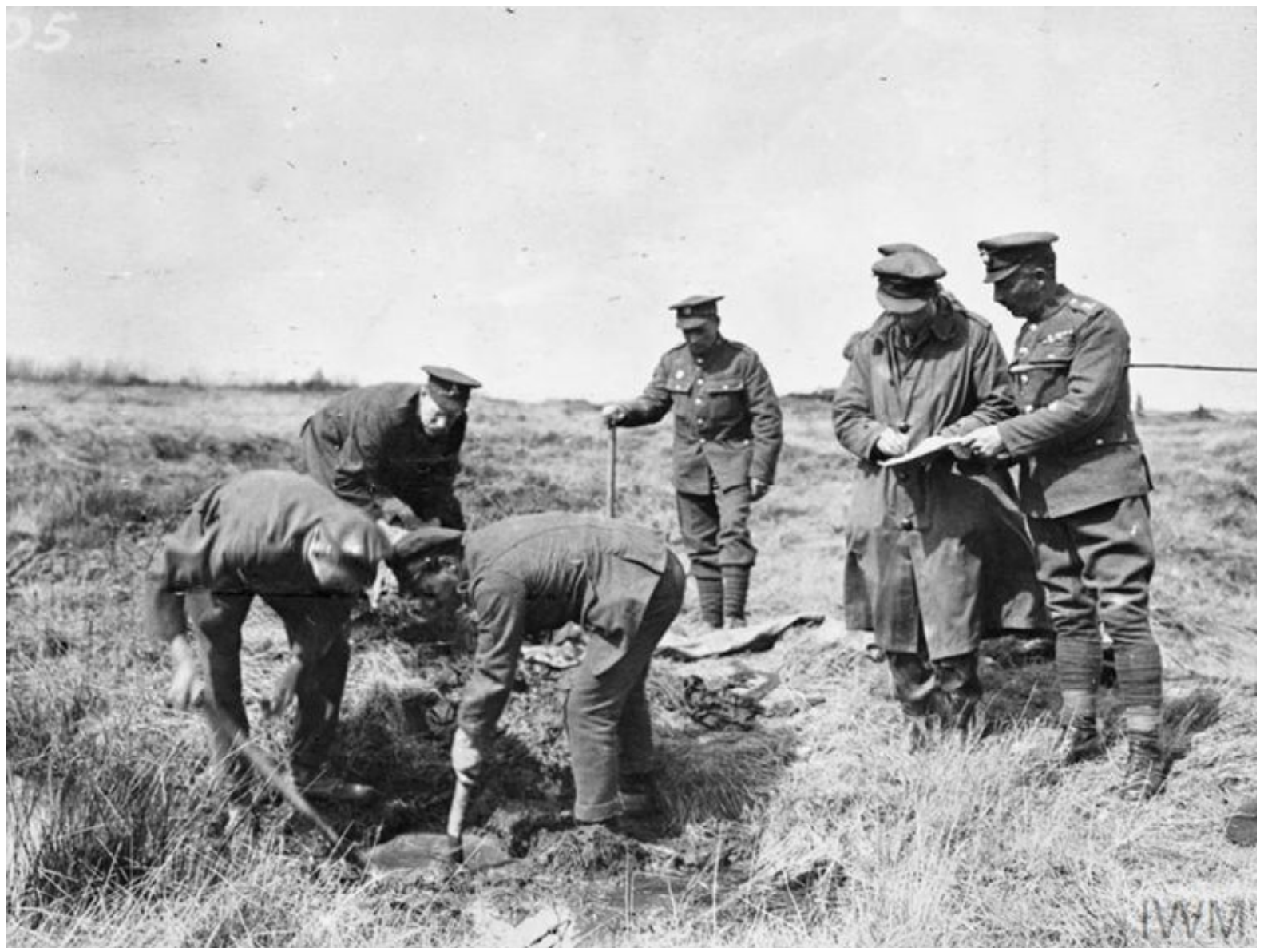

Figure 1: an exhumation party excavating a potential grave (C) IWM Q 100912

[https://www.iwm.org.uk/collections/item/object/205344032]

\section{Body Identification}

In modern mass disasters, great importance is placed on identification of the dead for legal and compassionate reasons (Buck and Briggs, 2016, p.520). This was also the case after the First World War, when exhumation units were tasked with trying to identify the deceased following their excavation.

"The body, having been exhumed, is placed upon the canvas, which has already been soaked in cresol and a careful search is made for any effects which may lead to identification. The pockets should be searched, and a special examination made of the neck, wrists and braces where identity discs may be found" (Crawford, 1919, cited in War Office, 1921)

Following a mass disaster, Forensic Anthropologists are often involved in the recovery and identification of the deceased. Current identification methods use fingerprints, DNA and dental comparison as the primary methods of identification, while visual inspection and personal effects are used to support a presumptive identification only (Sledzik and Mundorff, 2016). At the time of concentration, the scientific techniques used today were unavailable, and identification was based either on the presence of personal effects, an identity disc, the name 
on the cross over the grave (if present) or the pre-existing records of graves in the area. Now we would consider these types of evidence to be circumstantial, and would not confirm an identification based on this alone (Juhl and Einar Olsen, 2006, p.425). Bodies were not subjected to any medical examination to try and establish cause of death, and no records were kept of the condition of the remains. The only details recorded were of numerals or regimental badges which may have provided a partial identification.

Following the examination described, the bodies were wrapped in canvas, labelled with details on recovery location, an identification if established and any personal effects recovered, and then transferred to the nearest concentration cemetery for reinternment.

\section{Difficulties faced}

The work was not without its difficulties. In modern Forensic Archaeology, it is important to examine the landscape carefully for dips and depressions that could be the result of a clandestine grave or evidence of other soil disturbance (Cox et al., 2008). At the time of burial, most graves will have a mound of earth present. After burial, over time the soil in a grave will sink as it compacts and settles, with the potential for additional sinking as the body decomposes (Killam, 2004, p.34). By 1919, the land along the Western Front had been disturbed and churned over so many times, many of these features would have been impossible to distinguish (see Figure 2). To add to this problem, there was considerable additional material that been buried through artillery and mine action, making it challenging to differentiate between a mound which was a burial and a mound that was non-human buried material. It also made it dangerous due to the risk of unexploded ordinance while carrying out exhumations (Hanson, 2005).

Another significant problem was the lack of skilled workers involved in concentration. In modern cases it is known that successful search can be a challenge and is dependent on a number of factors including staff training (Fournet, 2016). Forensic Archaeologists are trained in the survey and excavation of complex features, including human remains (Skinner, Alempijevic and Djuric-Srejic, 2003) while Forensic Anthropologists are skilled in the recognition and interpretation of human bones, and both are required for successful excavation (Skinner and Sterenberg, 2005). The lack of these experts is reflected in the quality of the work undertaken during concentration. For example, one grave at Hooge Crater Cemetery when reexamined was found to contain the bones of a mule or horse as well as those of the solder buried within (War Office, 1921). This lack of anthropological or archaeological knowledge led to bones being missed during excavation, and soldiers' remains being incorrectly grouped together.

The variation in identification rates was also likely to be influenced by the lack of expertise. Research at Hooge Crater Cemetery has shown that errors in identification rates were more common in the early months of concentration but improved over time (Martin, 2020). This improvement is likely to be in part due to an increase in skill gained through experience, as well as improvement in the weather making searching, excavation and examination easier. 


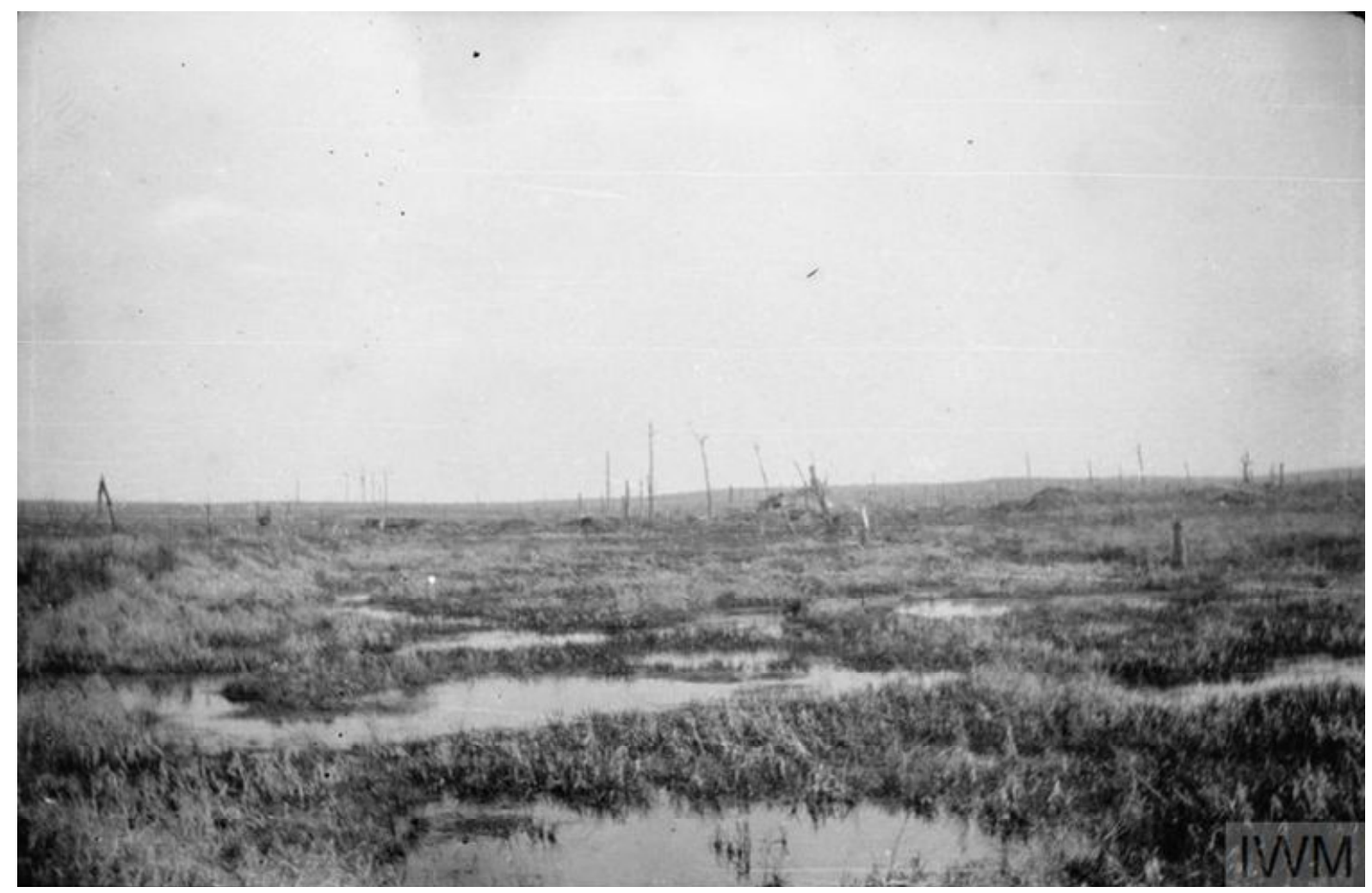

Figure 2: An example of the landscape that was being searched for individuals between 1919 and 1921 (C) IWM Q 100651 [https://www.iwm.org.uk/collections/item/object/205343774]

Finally, exhumation teams faced difficulty based on the sheer volume of graves and bodies that were present. With some areas having dozens, if not hundreds of graves present, it would have been very challenging to try and distinguish individual graves and features in a disturbed landscape. And while the exhumation teams successfully located and moved over 200,000 graves, between 1921 and 1931 nearly 33,000 additional Commonwealth bodies would be discovered through ploughing, farming and reconstruction work in the same area (Imperial War Graves Commission, 1931b).

Long term impact

In September 1921, the DGRE was disbanded, and no further active searching was carried out by the British in France and Belgium. The Imperial War Graves Commission took on responsibility for collecting and moving the bodies that continued to be found, and exhuming graves in cemeteries to confirm identification or solve duplications, but chose not to continue the search to locate soldiers' graves on the battlefields (Ware, 1921).

There is no evidence that the processes created by the DGRE for the searching, locating and exhumation of graves were used again. The groundbreaking work undertaken by the DGRE between 1919 and 1921 was forgotten and the experience gained was lost, leaving later practitioners to develop these processes again from scratch.

\section{Conclusions}

Between 1919 and 1921, the concentration of soldiers' graves took place on an unprecedented scale. Across the Western Front, 204,000 bodies were located and moved in a process which had never been seen before. While not completed by forensic or medical professionals, the task 
was completed following the basic principles of searching used in Forensic Archaeology, some of which are the same as modern day.

The work was completed with mixed results. While hundreds of thousands of graves were moved successfully, identification rates varied. Bodies would continue to be uncovered frequently for the following decade, and even now human remains are discovered on a regular basis.

The written records produced by Captain Crawford in 1919 are possibly the earliest documented instructions for a Forensic Archaeological search and excavation anywhere in the world. The described changes to plants, water and soil show an understanding of decomposition on the immediate environment, and the excavation techniques given reflect the difficulties in forensic excavation of human remains. While the technology available for detection of graves has changed in the last 100 years, many of the methods used for ground search are the same as those used frequently today.

\section{References}

Brown, M. and Osgood, R. (2009) Digging Up Plugstreet; the Archaeology of a Great War Battlefield. Yeovil: Haynes Publishing.

Buck, A. and Briggs, C. (2016) 'The Role of the Anthropolgist in Disaster Victim Identification', in Blau, S. and Ubelaker, D. (eds.) Handbook of Forensic Anthropology and Archaeology. New York: Routledge, pp. 520-531.

Chamberlain, A. and Parker Pearson, M. (2001) Earthly Remains: the History and Science of Preserved Human Bodies. London: British Museum Press.

Cox, M., Flavel, A., Hanson, I., Laver, J. and Wessling, R. (2008) The Scientific Investigation of Mass Graves. Cambridge: Cambridge University Press.

Crane, D. (2013) Empires of the Dead; How One Man's Vision Led to the Creation of WWI's War Graves. St Ives: William Collins.

Desfosses, Y., Jacques, A. and Prilaux, G. (2009) Great War Archaeology. Rennes: Editions Ouest-France.

Djuric, M., Dunjic, D., Djonic, D. and Skinner, M. (2007) 'Identification of Victims from Two Mass-Graves in Serbia: A Critical Evaluation of Classical Markers of Identity', Forensic Science International, 172(2-3), pp. 125-129.

Fathi, R. (2018) "“We refused to work until we had better means for handling the bodies". Discipline at the Australian Graves Detachment', First World War Studies, 9(1), pp. 35-56.

Fernandez-Alvarez, J.P., Rubio-Melendi, D., Martinez-Velasco, A., Pringle, J.K. and Aguilera, H.D. (2016) 'Discovery of a Mass Grave from the Spanish Civil War using Ground Penetrating Radar and Forensic Archaeology', Forensic Science International, 267, pp. e10e17.

Forbes, S., Perrault, K. and Comstock, J. (2017) 'Microscopic Post-Mortem Changes: the Chemistry of Decomposition', in Schotsmans, E., Marquez-Grant, N. and Forbes, S. (eds.) Taphonomy of Human Remains: Forensic Analysis of the Dead and the Depositional Environment. Chichester: John Wiley \& Sons, Ltd, pp. 26-38. 
Fournet, C. (2016) 'Forensic Sciences (Anthropology/Archaeology/Pathology) and International Criminal Justice', Science \& Justice, 56(5), pp. 303-304.

Garrido Varas, C. and Intriago Leiva, M. (2012) 'Managing Commingled Remains from Mass Graves: Considerations, Implications and Recommendations from a Human Rights Case in Chile', Forensic Science International, 219(1-3), pp. e19-e24.

Gassiot Ballbé, E. and Steadman, D.W. (2008) 'The Political, Social and Scientific contexts of Archaeological Investigations of Mass Graves in Spain', Archaeologies, 4(3), pp. 429_ 444.

Groen, W.J.M., Márquez-Grant, N. and Janaway, R.C. (2015) 'Concluding Remarks', in Groen, W. J. M., Márquez-Grant, N. and Janaway, R. C. (eds.) Forensic Archaeology: a Global Perspective. Chichester: John Wiley \& Sons, Ltd, pp. 515-536.

Haglund, W.D. (2002) 'Recent Mass Graves, An Introduction', in Haglund, W. D. and Sorg, M. H. (eds.) Advances in Forensic Taphonomy. Washington DC: CRC Press, pp. 243-262.

Haglund, W.D., Connor, M. and Scott, D.D. (2001) 'The Archaeology of Contemporary Mass Graves', Historical Archaeology, 35(1), pp. 57-69.

Hanson, N. (2005) The Unknown Soldier. London: Doubleday.

Holland, T. and Connell, S. (2016) 'The Search for and Detection of Human Remains', in Blau, S. and Ubelaker, D. (eds.) Handbook of Forensic Anthropology and Archaeology. New York: Routledge, pp. 167-180.

Hunter, J. and Cox, M. (2005) Forensic Archaeology: Advances in Theory and Practice. Abingdon: Routledge.

Hunter, J.R., Brickley, M.B., Bourgeois, J., Bouts, W., Bourguignon, L., Hubrecht, F., De Winne, J., Van Haaster, H., Hakbijl, T., De Jong, H., Smits, L., Van Wijngaarden, L.H. and Luschen, M. (2001) 'Forensic Archaeology, Forensic Anthropology and Human Rights in Europe.', Science \& Justice : Journal of the Forensic Science Society, 41(3), pp. 173-8.

Imperial War Graves Commission (1918) CWGC/1/1/7/B/42. WG 1294/3 Pt 1. Exhumation France and Belgium General File. Minutes from the sixth meeting of the Imperial War Graves Commission 19th November 1918. [Meeting Minutes]. Maidenhead: Commonwealth War Graves Commission Archives.

Imperial War Graves Commission (1931a) CWGC/1/1/7/B/45. WG 1294/3 PT.4. Exhumations - France and Belgium - General File. Letter dated October 1931 from IWGC to Mrs Gilmour. [Letter]. Maidenhead: Commonwealth War Graves Commission Archives.

Imperial War Graves Commission (1931b) CWGC/1/1/7/B/45. WG 1294/3 PT.4.

Exhumations - France and Belgium - General File. Letter dated September 1931 from the IWGC to Mrs Gilmour. [Letter]. Maidenhead: Commonwealth War Graves Commission Archives.

Juhl, K. and Einar Olsen, O. (2006) 'Societal Safety, Archaeology and the Investigation of Contemporary Mass Graves', Journal of Genocide Research, 8(4), pp. 411-435.

Junkins, E. and Carter, D. (2017) 'Relationships between Human Remains, Graves and the Despositional Environment', in Schotsmans, E., Marquez-Grant, N. and Forbes, S. (eds.) Taphonomy of Human Remains: Forensic Analysis of the Dead and the Depositional Environment. Chichester: John Wiley \& Sons, Ltd, pp. 145-154. 
Killam, E.W. (2004) The Detection of Human Remains. Illinois: Charles C Thomas Publishers.

Loe, L., Barker, C., Brady, K., Cox, M. and Webb, H. (2014) Remember Me To All: the Archaeological Recovery and Identification of Soldiers who Fought and Died in the Battle of Fromelles 1916. Oxford: Oxford Archaeology.

Longworth, P. (1985) The Unending Vigil; the History of the Commonwealth War Graves Commission. Barnsley: Pen \& Sword Books Ltd.

Mant, A.K. (1987) 'Knowlegdge Acquired Through Post-War Exhumations', in Boddington, A., Garland, A. N. and Janaway, R. C. (eds.) Death Decay and Reconstruction: Approaches to Archaeology and Forensic Science. Manchester: Manchester University Press, pp. 65-78.

Martin, V. (2020) PhD in First World War Burial Concentration in France and Belgium. Doctorial thesis in preparation. Cranfield University.

Robertshaw, A. and Kenyon, D. (2008) Digging the Trenches; the Archaeology of the Western Front. Barnsley: Pen \& Sword Military.

Skinner, M., Alempijevic, D. and Djuric-Srejic, M. (2003) 'Guidelines for International Forensic Bio-archaeology monitors of Mass Grave exhumations', Forensic Science International, 134(2-3), pp. 81-92.

Skinner, M. and Sterenberg, J. (2005) 'Turf wars: Authority and Responsibility for the Investigation of Mass Graves', Forensic Science International, 151(2-3), pp. 221-232.

Sledzik, P. and Mundorff, A. (2016) 'Forensic Anthropology in Disaster Response', in Blau, S. and Ubelaker, D. (eds.) Handbook of Forensic Anthropology and Archaeology. New York: Routledge, pp. 477-495.

Steele, C. (2008) 'Archaeology and the Forensic Investigation of Recent Mass Graves: Ethical Issues for a New Practice of Archaeology', Archaeologies, 4(3), pp. 414-428.

Sterenberg, J. (2009) 'Dealing with the Remains of Conflict; an International Response to Crimes Against Humanity, Forensic Recovery, Identification and Repatriation in the Former Yugoslavia', in Blau, S. and Ubelaker, D. (eds.) Handbook of Forensic Anthropology and Archaeology. California: Left Coast Press, pp. 416-425.

Taylor, W.M. (2015) 'War Remains: Contributions of the Imperial War Graves Commission and the Australian War Records Section to Material and National Cultures of Conflict and Commemoration', National Identities, 17(2), pp. 217-240.

Tuller, H. and Durić', M. (2006) 'Keeping the Pieces Together: Comparison of Mass Grave Excavation Methodology', Forensic Science International, 156(2-3), pp. 192-200.

Vanezis, R. (1999) 'Investigation of Clandestine Graves Resulting from Human Rights Abuses', Journal of Clinical Forensic Medicine, 6(6), pp. 238-242.

War Office (1921) CWGC/1/1/7/B/48. DGRE 46. Exhumations - Report Of Committee Of Enquiry. [Photocopy of T.S Report]. Maidenhead: Commonwealth War Graves Commission Archives.

Ware, F. (1921) CWGC/1/1/5/26. WG 1294 PT.1. Exhumation by IWGC-General File. Letter from Fabian Ware dated 15 September 1921. [Letter]. Maidenhead: Commonwealth War Graves Commission Archives. 